Vol. 2, No. 1, Juni 2018, Hal. 93-100

e-ISSN 2614-5758 | p-ISSN 2598-8158

Crossref :https://doi.org/10.31764/jmm.v2i1.1386

\title{
PENDAMPINGAN MENGHINDARI SEXUAL ABUSE PADA SISWA SMA CURUP BENGKULU
}

\author{
Dheni Koerniawan ${ }^{1}$, Ketut Suryani ${ }^{2}$, Maria Tarisia Rini $^{3}$, Sagita Bahari ${ }^{4}$ \\ ${ }^{1,2,3,4}$ Prodi Ilmu Keperawatan dan Ners, Universitas Katolik Musi Charitas, Indonesia \\ dheni@ukmc.ac.id, suryani@ukmc.ac.id, tarisia_rini@ukmc.ac.id
}

\begin{abstract}
ABSTRAK
Abstrak: Perubahan hormon selama perkembangan remaja dapat menjadikan remaja mengalami kemelut (turmoil) dalam dirinya secara psikoseksual. Hal tersebut dapat memicu terjadinya perilaku menyimpang yang dilakukan oleh remaja atau dialami oleh remaja sehingga menempatkan remaja dapat menjadi pelaku atau korban dalam penyimpangan seksual seperti kekerasan seksual (sexual abuse). Oleh karena itu, edukasi dan pendampingan sejak dini perlu dilakukan untuk meningkatkan self-care remaja mengidentifikasi adanya risiko terjadinya sexual abuse baik yang dapat terjadi pada dirinya atau pun lingkungannya. Hal inilah yang menjadi tujuan dalam kegiatan pengabdian kepada masyarakat sehingga luaran yang diharapkan adalah remaja mampu mengenali kondisi atau orang yang berpotensi mengakibatkan terjadinya sexual abuse, mengamankan diri dengan mencegah munculnya kesempatan terjadinya sexual abuse, dan melaporkan kondisi atau orang yang berpotensi serta kejadian sexual abuse. Kegiatan dilakukan dengan metode edukasi dan konseling. Hasil abdimas menunjukkan bahwa sebagian besar peserta berusia 17 tahun dan berjenis kelamin perempuan, area pribadinya pernah disentuh orang lain dan korban sexual abuse verbal, pertama kali mengalami sexual abuse saat berusia 16 tahun, mengenal pornografi dan pornoaksi ketika berusia 15 tahun, serta menjadikan orang tua dan sahabat sebagai pihak yang dipercaya dalam melaporkan peristiwa sexual abuse baik yang dialami atau disaksikan peserta.
\end{abstract}

Kata kunci: Pendampingan Remaja; Sexual Abuse; Self-care

Abstract: Hormonal changes is going along with adolescence growing so he/she has turmoil especially in psychosocial aspect. This could precipitate the deviant behavior that adolescence done or suffered. It can make adolescence be a doer or victims of sexual abuse. Thus, early education and accompaniment needed to be done to enhanced adolescence self-care to identify the risk of sexual abuse that can be happened with him/herself or in their environment. This was the aims of our public services so it has outcome that adolescence able to know condition or someone which has potential to be a sexual abuse, protecting self with preventing that potential to become sexual abuse, and reporting it. This activity done as an education and counseling. The result showed mainly of participants are 17 year old and girls, personal body parts had been touched by other people and as victims, first time being victim at 16 years old, knowing pornography and pornoaction at 15 years old, and made parents and best friends as trusted people to to report even being a victim or witness.

Keywords: Youth mentoring; Sexual Abuse; Self-Care

\section{A. LATAR BELAKANG}

Perubahan yang terjadi pada remaja muncul karena adanya perubahan hormonal yang dihasilkan oleh kelenjar endokrin tubuh dan kemudian memicu perkembangan secara fisik, emosional dan mental, serta seksualitas (Tiara, Deliana, \& Hendriyani, 2013). Adaptasi remaja terhadap 
perubahan yang terjadi pada tubuhnya mempengaruhi bagaimana remaja juga beradaptasi dalam konsep diri, peran, dan interdependen (saling ketergantungan) sehingga menuntut remaja memiliki mekanisme koping kognitif-persepsi melalui pembelajaran yang dialami remaja dari dirinya, orang lain, dan lingkungan sekitar [1]. Mekanisme koping dan interaksi remaja dengan lingkungannya yang kemudian membuat remaja memiliki adaptasi yang adaptif atau pun maladaptif [2]

Adaptasi maladaptif dapat membuat remaja menjadi pelaku perilaku menyimpang secara fisik, emosional, mental, dan seksual. Komisi Perlindungan Anak Indonesia (KPAI) mencatat bahwa terdapat 1.032 kasus pornografi dan cybercrime dari tahun 2011 hingga 2014 [3]. Kasus pengaduan anak sebagai pelaku kekerasan seksual (pemerkosaan, pencabulan, sodomi/ pedofilia) meningkat dari 22 kasus menjadi 31 kasus selama satu tahun (2015-2016) [4]. Seorang remaja putri di Rejang Lebong yang menjadi korban perkosaan 14 laki-laki yang masih di bawah umur [5]. Beberapa kasus sexual abuse sulit terungkap dikarenakan korban tidak mampu melaporkan kejadian karena diancam, pelaku merupakan orang terdekat, atau trauma dan aib.

Jumlah anak sebagai korban kekerasan seksual menurun dari 218 kasus menjadi 156 kasus [4] sebagai dampak dari diberlakukannya Perpu No. 1 tahun 2016 tentang Perlindungan Anak baik sebagai korban atau pun saksi sehingga memungkinkan korban atau saksi memiliki keberanian untuk mengungkap kasus kekerasan seksual yang dialaminya atau disaksikannya. Oleh karena itu, perlu dilakukan penguatan kepada anak khususnya remaja untuk memiliki keyakinan dan kemampuan dalam mencegah, menghindari, atau melaporkan kasus sexual abuse.

Keperawatan menurut Orem memandang individu sebagai seseorang yang terintegrasi dengan perawat dalam memberikan perawatan bagi dirinya atau bagi orang lain [2] dengan mengidentifikasi kebutuhan dan berupaya memenuhi apa yang dirinya atau orang lain butuhkan [1] Remaja sebagai seorang individu yang membutuhkan pendampingan dalam beradaptasi perkembangan yang terjadi pada dirinya serta dampak dari perkembangan tersebut. Dalam konteks tersebut, orang-orang yang berada di sekeliling remaja seperti perawat, orang tua, sekolah, dan teman sebaya merupakan agen atau pihak yang termasuk ke dalam sistem keperawatan Orem. Pihak-pihak tersebut (yang selanjutnya disebut dengan istilah agen menurut Orem) dapat membantu remaja menuju kondisi sehat dan sejahtera. Sehat adalah kondisi yang secara struktural dan fungsional yang utuh dan dalam kondisi baik secara individual atau kelompok.

Teori Orem mendeskripsikan self-care sebagai konsep kenapa dan bagaimana individu merawat dirinya untuk mempertahankan hidup, sehat fungsional, berkembang, dan sejahtera dengan memenuhi kebutuhan dari perkembangan yang dialaminya [1]. Kebutuhan self-care remaja dalam konteks sexual abuse meliputi interaksi sosial, pencegahan bahaya, dukungan atau promosi fungsional dan perkembangan remaja secara individu atau kelompok; pencegahan dari dampak perkembangan yang dialami remaja; serta kebutuhan perawatan diri terkait penyimpangan kesehatan yang dialami remaja, ketidakmampuan remaja, dan kemampuan remaja membantu dirinya dan orang lain (Gustina, 2017). 
Edukasi merupakan salah satu upaya yang dapat meningkatkan perilaku sehat berdasarkan faktor-faktor yang mempengaruhi perilaku individu [6]. Model Promosi Kesehatan Pender memungkinkan individu memiliki komitmen untuk berperilaku sehat dan mempertahankan komitmen tersebut dari tantangan dan kendala yang mungkin akan dihadapi [7]. Dengan demikian pendekatan Roy, Orem dan Pender dalam pemberian edukasi pada remaja dapat meningkatkan kemampuan remaja untuk berkomitmen dan bertindak tegas terhadap sexual abuse yang terjadi atau berpotensi terjadi pada lingkungannya.

Berdasarkan identifikasi awal, diperoleh hasil wawancara mahasiswa yang berasal dari daerah mitra, yaitu:

"di daerah itu banyak sekali anak-anak yang suka minum-minum keras, nongkrong-nongkrong di jalan".

Selain itu ada berapa kasus kekerasan seksual yang menimpa seorang anak perempuan yang ada di sana [5]. Oleh karena itu, dirumuskan permasalahan mitra sebagai berikut: (1) Remaja belum memiliki kewaspadaan terhadap sexual abuse yang berpotensi terjadi pada diri atau lingkungannya; dan (2) Remaja perlu meningkatkan kemampuan diri untuk mencegah dan melaporkan potensial atau aktual kejadian sexual abuse baik pada diri sendiri atau lingkungan sekitarnya.

Sehingga luaran yang diharapkan adalah: (1) Peserta mampu mengidentifikasi kondisi atau individu yang berpotensi terjadi sexual abuse; (2) Peserta mampu mengidentifikasi cara pencegahan dan pengamanan diri terhadap sexual abuse; dan (3) Peserta mampu mengidentifikasi cara melaporkan kondisi atau orang yang berpotensi terjadi sexual abuse dan kejadian sexual abuse.

\section{B. METODE PELAKSANAAN}

Kegiatan pengabdian kepada masyarakat (Abdimas) dilakukan dengan melakukan identifikasi awal yang kemudian dilanjutkan dengan persetujuan mitra terhadap diadakannya Abdimas serta perencanaan pelaksanaan kegiatan. Edukasi dan konseling dilakukan pada kegiatan inti Abdimas yang kemudian dilakukan survei pengalaman sexual abuse dan hal yang berkaitan, dan diakhiri dengan evaluasi kegiatan melalui kuesioner.

Edukasi dan konseling merupakan metode yang dipilih tim sebagai bentuk aplikasi teori keperawatan Adaptasi Roy, Self-Care Orem, dan Health Promotion Model Pender. Dua metode ini dipilih sebagai sarana untuk melakukan pendekatan pada peserta karena sexual abuse merupakan topik yang sensitif dan sulit diungkapkan oleh sebagian besar korban atau saksi dari kejadian sexual abuse. Oleh karena itu, tim memilih pendekatan dengan metode edukasi dan konseling.

\section{HASIL DAN PEMBAHASAN}

Berdasarkan pelaksanaan kegiatan diperoleh informasi terkait karakteristik mitra, kemampuan mitra, pengalaman mitra, dan penjelasan lain terkait sexual abuse. 


\section{Karakteristik Peserta}

Berdasarkan pendataan diperoleh informasi tentang mitra sesuai Tabel 1 berikut.

Tabel 1. Distribusi Karakteristik Peserta

\begin{tabular}{lcl}
\hline Karakteristik & f & \% \\
\hline Usia & & \\
\hline 16 tahun & 17 & 34,7 \\
17 tahun & 25 & 51 \\
18 tahun & 7 & 14,3 \\
\hline Jenis Kelamin & & \\
\hline Laki-laki & 22 & 44,9 \\
Perempuan & 27 & 55,1 \\
\hline
\end{tabular}

Tabel 1 memperlihatkan bahwa sebagian besar peserta berusia 17 tahun dan berjenis kelamin perempuan. Hal ini terjadi karena peserta merupakan siswa/i kelas XII yang memiliki usia dalam rentang $17-18$ tahun.

\section{Kemampuan identifikasi bentuk sexual abuse berdasarkan pengalaman peserta}

Setelah dilakukan edukasi tiap peserta diminta untuk mengidentifikasi hal-hal yang pernah dialami apakah termasuk ke dalam bentuk-bentuk sexual abuse atau tidak.

Tabel 2. Distribusi Frekuensi Pengalaman sexual abuse Peserta

\begin{tabular}{llllll}
\multicolumn{1}{c}{ Kategori } & Ya & \multicolumn{3}{c}{ Tidak } \\
\cline { 2 - 6 } & f & $\%$ & \multicolumn{2}{c}{ f } & $\%$ \\
\hline Korban & & & & \\
\hline $\begin{array}{l}\text { Area pribadi pernah disentuh orang lain } \\
\text { Pernah dibuat untuk menyentuh area pribadi } \\
\text { orang lain }\end{array}$ & 18 & 36,4 & 14 & 8,6 \\
\hline Dipaksa melakukan hubungan seksual & 2 & 4,1 & 47 & 95,3 \\
\hline $\begin{array}{l}\text { Dibujuk secara halus melakukan hubungan } \\
\text { seksual }\end{array}$ & 6 & 12,2 & 43 & 87,8 \\
\hline$\quad$ Sexual abuse verbal & 38 & 77,6 & 11 & 22,4 \\
\hline Saksi & 23 & 46,9 & 26 & 53,1 \\
\hline Mengalami stress atau depresi & 12 & 24,5 & 37 & 75,5 \\
\hline
\end{tabular}

Tabel 2 menunjukkan bahwa area pribadi (kemaluan, bokong, leher, dada, bibir) dari 35 peserta pernah disentuh orang lain dan dirasa tidak nyaman $(71,4 \%)$. Begitu juga 18 peserta merasa pernah dibuat untuk menyentuh area pribadi orang lain $(36,7 \%)$ dan dirasa tidak nyaman. Selain itu 2 peserta pernah mengalami pemaksaan $(4,1 \%)$ dan 6 peserta dibujuk secara halus untuk melakukan seksual $(12,2 \%)$. Sedangkan 38 peserta pernah mengalami pelecehan secara verbal (bersiul, menyebut istilah bohay, montok, seksi) (77,6\%). Peserta yang pernah menyaksikan sexual abuse sebanyak 23 orang $(46,9 \%)$ dan 12 peserta pernah merasa stres atau depresi setelah mengalami sexual abuse. Berdasarkan hasil diskusi dan survei melalui kuesioner tersebut menunjukkan bahwa 
sebagian besar peserta mampu mengidentifikasi bahwa peristiwa yang telah mereka alami termasuk dalam pelecehan seksual dalam berbagai bentuk.

\section{Pengalaman Sexual Abuse Berdasarkan Jenis Kelamin}

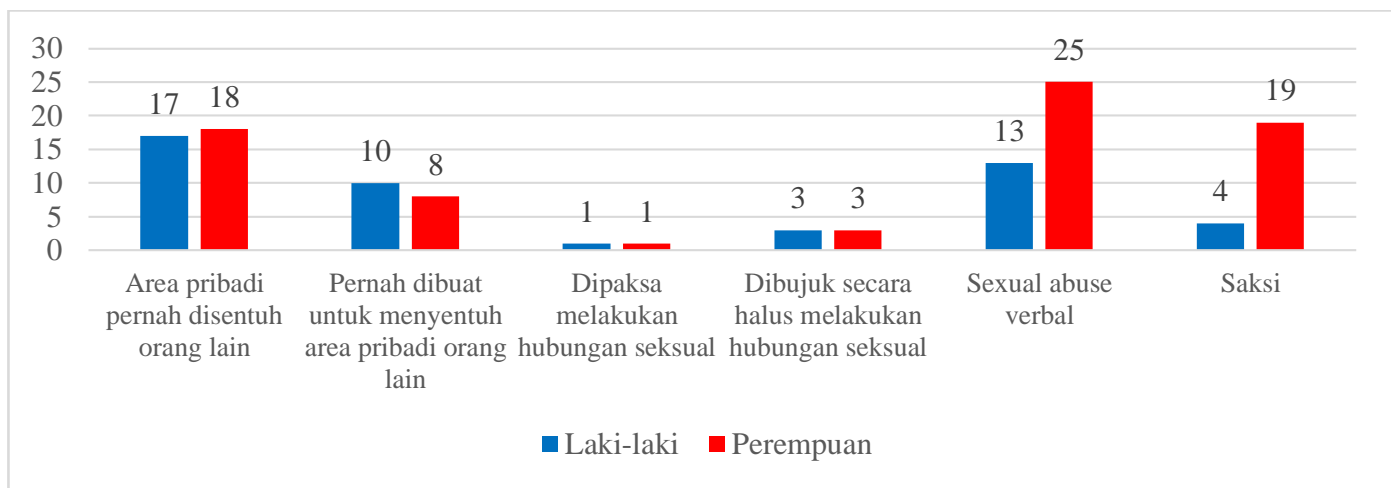

Gambar 1. Distribusi Frekuensi Pengalaman sexual abuse Berdasarkan Jenis Kelamin Peserta

Gambar 1 memperlihatkan data frekuensi jumlah peserta/i yang mengalami bentuk-bentuk sexual abuse saja, sedangkan yang tidak mengalami tidak dimunculkan. Tampilan data pada Gambar 1 memperlihatkan bahwa dari semua bentuk sexual abuse peserta/i, sebagian besar yang pernah mengalami adalah siswi. Pengalaman bentuk abuse yang paling ringan adalah bentuk non-verbal dan lebih banyak dialami oleh perempuan. Hal ini umumnya terjadi ketika perempuan lebih banyak menjadi korban pelecehan, selain dikarenakan pelakunya adalah laki-laki, tetapi juga karena perempuan dianggap lebih lemah sehingga menjadi sasaran dalam perilaku abuse. Oleh karena itu, meningkatkan kemampuan siswi (tetapi tidak terbatas hanya pada siswi, tetapi juga peserta) dalam mewaspadai dan bertindak tegas (salah satunya mengatakan tidak) terhadap pelaku, akan mengurangi intensitas paksaan atau keberanian pelaku dalam matan untuk melakukan abuse.

\section{Pengalaman pertama kali mengalami sexual abuse}

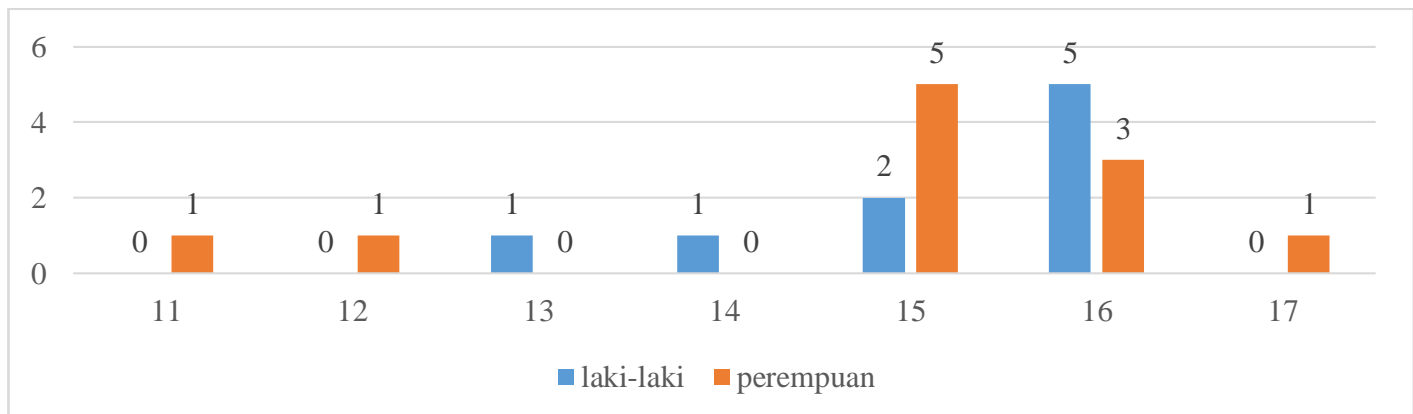

Gambar 2. Distribusi frekuensi usia pertama kali mengalami sexual abuse berdasarkan jenis kelamin peserta 
Gambar 2 memperlihatkan bahwa sebagian peserta pertama kali mengalami sexual abuse pada usia 16 tahun (16,33\%) yaitu pada saat berada di sekolah atas (SMA), serta ada juga yang sudah mengalaminya saat sekolah dasar (usia 11 tahun). Peserta memiliki pengalaman sexual abuse yang tidak hanya dapat terjadi pada remaja saja tetapi juga masa anak-anak. Hal ini menunjukkan bahwa kejadian kekerasan secara seksual baik dalam bentuk fisik maupun verbal sudah terjadi dimulai pada masa anak-anak. Pelaku memandang anak-anak merupakan individu yang polos dan mudah dibujuk karena dianggap tidak mengerti apak yang sedang direncanakan atau dilakukan oleh pelaku, jadi biasanya korban diberikan sesuatu yang menarik atau diancam untuk tidak memberitahu sexual abuse yang terjadi pada korban. Tidak jarang terjadi bahwa individu yang pernah menjadi korban atau saksi dapat juga memicu individu tersebut menjadi pelaku di kemudian hari, sehingga siklus fenomena ini terus bergulir. Oleh karena itu, edukasi dan pendampingan sejak dini pada anak dan remaja mengenai area pribadi tubuhnya dan kemampuan menjadi sangat penting untuk mewaspadai potensial terjadinya sexual abuse pada diri ataupun lingkungan sekitarnya sehingga bukan hanya secara individual tetapi secara komunal dapat membentengi diri dari pelaku sexual abuse.

\section{Faktor predisposisi}

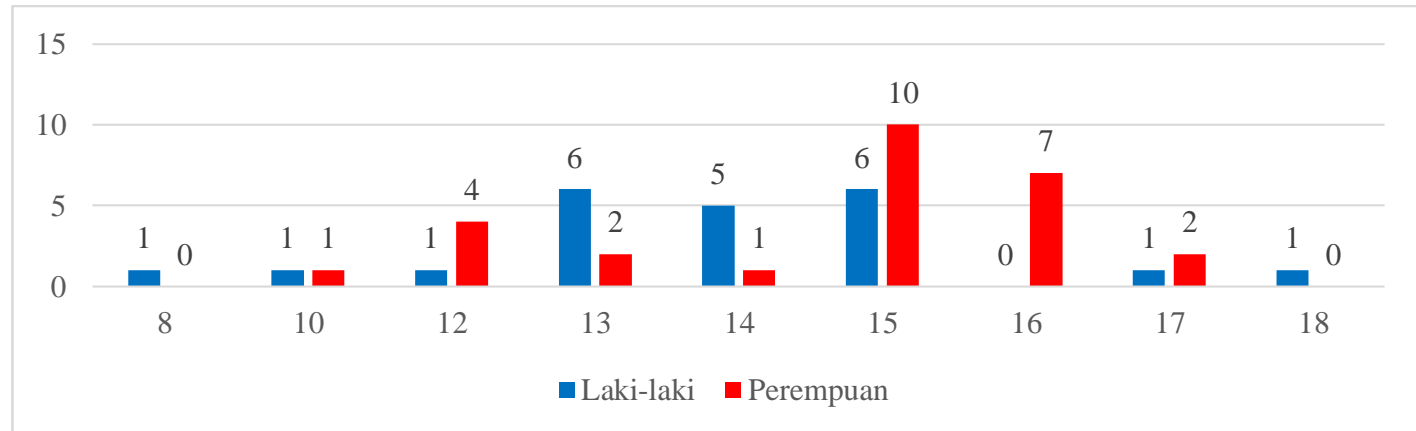

Gambar 3. Distribusi frekuensi usia pertama kali mengenal pornografi dan porno aksi peserta 2018

Gambar 3 menunjukkan bahwa sebagian besar peserta sudah mengenal pornografi dan porno aksi sejak usia 15 tahun $(32,7 \%)$ yang berarti sedang dalam jenjang sekolah menengah pertama. Tetapi ada juga yang sudah mengenal sejak usia 8 tahun (2\%) yang berarti sedang dalam jenjang sekolah dasar. Paparan seksualitas dini pada saat perkembangan anak usia sekolah akhir sampai dengan remaja secara hormonal serta aspek psikoseksual dan psikososial dapat menjadi predisposisi anak memiliki kontrol yang kurang terhadap gejolak (desire) dan kemelut (turmoii) dalam aspek seksualitas. Hal tersebut dapat kemudian bermanifestasi menjadi perilaku yang menjurus kepada perilaku seksualitas yang menyimpang baik secara intrapersonal atau pun interpersonal seperti mengakses pornografi atau porno aksi, memberikan penyebutan seksual pada teman atau orang lain yang berbeda jenis kelamin, atau bahkan mencoba tindakan secara fisik dalam konteks seksualitas. Selain itu, rasa ingin tahu dan ingin 
mencoba juga dapat menjadi presipitasi bagi anak sampai akhirnya melakukan tindak seksualitas bahkan mengarah pada pelecehan seksual.

6. Pihak atau orang yang dipercayai untuk berbagi cerita atau melaporkan jika mengalami atau menyaksikan kejadian sexual abuse

Tabel 3. Pihak atau orang yang dipercayai untuk berbagi cerita atau melaporkan jika mengalami atau menyaksikan sexual abuse

\begin{tabular}{lll} 
Pihak atau Orang yang dipercaya & f & \% \\
\hline Orang tua & 14 & 28,6 \\
\hline Orang tua, sahabat & 14 & 28,6 \\
\hline Sahabat & 5 & 10,2 \\
\hline Orang tua, saudara & 3 & 6,1 \\
\hline Orang tua, saudara, sahabat & 2 & 4,1 \\
\hline Orang tua, pemuka agama, guru & 2 & 4,1 \\
\hline Orang tua, guru, pihak berwajib & 2 & 4,1 \\
\hline Tuhan & 1 & 2,0 \\
\hline Teman terdekat, orang tua, pihak berwajib & 1 & 2,0 \\
\hline Orang tua, sahabat, guru & 1 & 2,0 \\
\hline Orang tua, Tuhan & 1 & 2,0 \\
\hline Orang tua, saudara, guru & 1 & 2,0 \\
\hline Orang tua, Tuhan, sahabat & 1 & 2,0 \\
\hline Orang tua, saudara, guru, sahabat & 1 & 2,0 \\
\hline
\end{tabular}

Tabel 3 merupakan jawaban yang diberikan peserta melalui kuesioner yang diisi secara kualitatif. Hasilnya memperlihatkan bahwa sebagian besar peserta percaya kepada orang tua dan sahabat ketika ingin bercerita atau melaporkan kejadian sexual abuse yang dialami atau disaksikan. Selain itu, pihak lain yang dipercaya peserta adalah saudara, guru, pemuka agama, pihak berwajib, dan ada yang menyatakan bercerita kepada Tuhan melalui doa.

Orang tua dipercaya karena merupakan orang yang paling dekat dan dirasa sebagai pelindung ketika remaja mengalami masalah atau kesulitan sehingga diharapkan dapat memberikan pertolongan dan solusi. Selain itu, tampak juga ciri dari tumbuh kembang remaja ketika teman sebaya menjadi bagian dalam hidup remaja dimana remaja menghabiskan waktu kesehariannya lebih banyak bersama temantemannya yang sebaya sehingga kepada temannya lah remaja sering bercerita, berkeluh kesah, serta mencari pertolongan dan solusi atas masalah dan kesulitan yang dialaminya.

\section{SIMPULAN DAN SARAN}

Hasil Abdimas menunjukkan bahwa sebagian besar peserta berusia 17 tahun dan berjenis kelamin perempuan, area pribadinya pernah disentuh orang lain dan korban sexual abuse verbal, pertama kali mengalami sexual abuse saat berusia 16 tahun, mengenal pornografi dan pornoaksi ketika berusia 15 tahun, serta menjadikan orang tua dan sahabat sebagai pihak 
yang dipercaya dalam melaporkan peristiwa sexual abuse baik yang dialami atau disaksikan peserta.

\section{UCAPAN TERIMA KASIH}

Tim penulis mengucapkan terima kasih kepada Rektor serta Lembaga Penelitian dan Pengabdian Pada Masyarakat (LPPM) Universitas Katolik Musi Charitas (UKMC) yang telah mendanai kegiatan pengabdian ini, begitu juga kepada Kepala Sekolah salah satu SMA swasta di Curup Bengkulu sehingga terlaksana dengan baik.

\section{DAFTAR RUJUKAN}

Alligood, M. R. (2014). Nursing Theorists and Their Work. In Elsevier Mosby (8th ed.). https://doi.org/10.5172/conu.2007.24.1.106a

Gustina, E. (2017). Komunikasi Orangtua-Remaja Dan Pendidikan Orangtua Dengan Perilaku Seksual Berisiko Pada Remaja. Unnes Journal of Public Health, 6(2), 131. https://doi.org/10.15294/ujph.v6i2.13734

KPAI. (2014). Pelaku Kekerasan terhadap Anak tiap Tahun meningkat.

KPAI. (2016). Kasus Pengaduan Anak berdasarkan Klaster Perlindungan Anak. Jakarta.

Liputan6. (2016). Kronologi Kasus Kematian Yuyun di tangan 14 ABG Bengkulu.

McEwen, M., \& Wills, E. M. (2011). Theoritical Basis for Nursing. Philadelphia: Lippincott Williams \& Wilkins.

Pender, N. J., Murdaugh, C. L., \& Parsons, M. a. (2011). The health promotion model. Health Promotion in Nursing Practice, 4, 1-17.

Peterson, S. J., \& Bredow, T. S. (2013). Middle Range Theories: Application to Nursing Research (3rd ed.). Philadelphia: Wolters Kluwer Health | Lippincott Williams \& Wilkins.

Tiara, D. F., Deliana, S. M., \& Hendriyani, R. (2013). Faktor-Faktor Penyebab Perilaku Seksual Menyimpang Pada Remaja Tunagrahita SLB N Semarang. Developmental and Clinical Psychology, 2(1), 26-32. 